\title{
NOTE
}

\section{Comparative susceptibility of two different genetic types of tilapia to Neobenedenia sp. (Monogenea)}

\author{
Miguel Rubio-Godoy ${ }^{1, *}$, Adriana Montiel-Leyva ${ }^{2}$, J. Antonio Martínez-Hernández ${ }^{3}$ \\ ${ }^{1}$ Instituto de Ecología, A.C., Red de Biología Evolutiva, km 2.5 ant carretera a Coatepec, Xalapa, Veracruz 91070, México \\ ${ }^{2}$ Centro de Enseñanza, Investigación y Extensión en Ganadería Tropical (CEIEGT), Facultad de Medicina Veterinaria \\ y Zootecnia, Universidad Nacional Autónoma de México, km 5.5 Carretera Federal Martínez de la Torre-Tlapacoyan, \\ Martínez de la Torre, Veracruz 93600, México \\ ${ }^{3}$ Acuario de Veracruz, Blvd., Manuel Ávila Camacho s/n, Playón de Hornos, Veracruz, Veracruz 91700, México
}

\begin{abstract}
Two different genetic types of tilapia, Mozambique tilapia Oreochromis mossambicus (MT), and Pargo-UNAM (PU; a synthetic hybrid whose genetic composition is $50 \%$ Florida red tilapia, $25 \%$ Rocky Mountain tilapia, and $25 \%$ red variant Oreochromis niloticus), were acclimatized to salinity and exposed to seawater from the Gulf of Mexico off the port of Veracruz, Mexico. Both fish types were infected by the monogenean ectoparasite Neobenedenia sp. and were killed within 2 to $3 \mathrm{wk}$. A crude worm extract was prepared from whole specimens collected during the original outbreak and used to immunize naïve hosts of the same 2 types of tilapia. Immunized fish were then exposed to seawater, which resulted in Neobenedenia sp. infection. Immunization did not confer any protection against Neobenedenia sp. infection. However, the experiment enabled detailed analysis of the dynamics of infection and comparison of the effects of the parasite on the 2 host types. Although both tilapia types exhibited similar resistance to infection (as they harbored similar parasite burdens in the early phase of infection), PU is less tolerant to Neobenedenia sp., as a mean parasite abundance of ca. 50 worms fish ${ }^{-1}$ killed all hosts within a fortnight, while $22 \%$ of MT survived up to $3 \mathrm{wk}$, harboring a mean parasite abundance of ca. 900 worms fish $^{-1}$. Our results suggest that, as reported elsewhere, Neobenedenia sp. could negatively affect mariculture off the Mexican coast of the Gulf of Mexico.
\end{abstract}

KEY WORDS: Tilapia $\cdot$ Oreochromis $\cdot$ Monogenea $\cdot$ Neobenedenia $\cdot$ Resistance $\cdot$ Tolerance

\section{INTRODUCTION}

Tilapia Oreochromis spp. (Cichlidae) are commercially important fish (Lazard 2009): global production of cultured tilapia now approaches 3 million $t$ per annum, second only to that of carp (common carp, grass carp, silver carp, bighead carp, and crucian carp) production (FAO 2008). These freshwater cichlid fish are extremely adaptable and, after acclimatization to salinity, can grow in seawater (Breves et al. 2010). This flexibility enables the use of sea cages to grow tilapia, which markedly increases the production capacity of countries with extensive coastlines. For this reason, trials were started to assess the productive performance in seawater of 2 genetic types of tilapia currently reared in Veracruz, Mexico; namely Mozambique tila- pia (MT) Oreochromis mossambicus Peters, and PargoUNAM (PU), a red synthetic hybrid tilapia whose genetic composition is $50 \%$ Florida red tilapia, $25 \%$ Rocky Mountain tilapia, and 25\% red variant Oreochromis niloticus L. (Muñoz-Córdova \& Garduño-Lugo 2003).

MT and PU acclimatized well to salinity, but were rapidly infected with Neobenedenia sp. when exposed to unfiltered seawater from the Gulf of Mexico and died within 2 to $3 \mathrm{wk}$ - although mortality rates were noticeably higher for PU than for MT. Previously, Neobenedenia melleni (MacCallum 1927) Yamaguti, 1963, has been shown to infect tilapia reared in sea cages in Hawaii (Kaneko et al. 1988), Martinique (Gallet de St. Aurin et al. 1990), the Bahamas (Mueller et al. 1992, Cowell et al. 1993, Ellis \& Watanabe 1993), and 
Jamaica (Robinson et al. 1992, 2008). There are no reports of Neobenedenia spp. infecting wild fish off Veracruz, Mexico, but several tropical teleosts have been recorded to harbor $N$. melleni in the Caribbean Sea (Kohn et al. 2006). Of the fish listed by Kohn et al. (2006) as hosts for $N$. melleni, we highlight 7 species that (1) occur in coral reefs off Veracruz; and (2) are held at the Acuario de Veracruz, where they recurrently present Neobenedenia sp. infections. These 7 species are doctorfish Acanthurus chirurgus Bloch (see Bunkley-Williams \& Williams 1994, Sikkel et al. 2009), rock hind Epinephelus adscensionis L. (see Mueller et al. 1994), yellowtail snapper Ocyurus chrysurus Bloch (see Gallet de St. Aurin et al. 1990, Mueller et al. 1994), smooth trunkfish Rhinesomus (= Lactophrys) triqueter L. (see Nigrelli 1947), spot-fin porcupinefish Diodon hystrix L. (see Nigrelli 1947), spotfin butterflyfish Chaetodon ocellatus Bloch (see Nigrelli 1947), and French angelfish Pomacanthus paru Bloch (see Nigrelli 1947). The original description of $N$. melleni was based on specimens collected from fish kept at the New York Aquarium (MacCallum 1927), where outbreaks of the parasite continued for decades (Jahn \& Kuhn 1932, Nigrelli \& Breder 1934, Nigrelli 1947, Thoney \& Hargis 1991). N. melleni and N. girellae (Hargis, 1955) Yamaguti, 1963 are infamous pathogens affecting wild and farmed fishes worldwide (Whittington 2004). These might be the same species, as Whittington \& Horton (1996) synonymized N. girellae with $N$. melleni; however this decision has not been accepted universally. These ectoparasites probably form a complex of morphologically indistinguishable species (Whittington 2004) which, unlike most monogeneans, exhibit low host specificity, as they have been recorded from the surfaces of more than 100 captive and wild teleost species in more than 30 families from 5 orders (Deveney et al. 2001). Given their negative impact on marine fish culture, considerable efforts have been made to control Neobenedenia spp., particularly the pathogenic $N$. melleni and $N$. girellae, including biological control by means of cleaner fish (Cowell et al. 1993) and cleaner shrimp (McCammon et al. 2010); treatment of infected hosts with hyposaline (Ellis \& Watanabe 1993), freshwater (Kaneko et al. 1988, Fajer-Ávila et al. 2008, Ohno et al. 2009), or calcium and magnesium ion-free buffer baths (Ohashi et al. 2007); chemical treatment with copper sulphate and formalin (Thoney \& Hargis 1991); pharmacological treatment with trichlorfon (Gallet de St. Aurin et al. 1990) and praziquantel (Hirazawa et al. 2004); and attempts at immunization (Bondad-Reantaso et al. 1995, Hatanaka et al. 2005).

Neobenedenia sp. collected during the first outbreak on tilapia in the Acuario de Veracruz was used to prepare a crude worm extract, with which we attempted the immunization of naïve MT and PU against the parasite. The challenge of immunized and control hosts enabled us to characterize the dynamics of infection and to compare the susceptibility of the 2 genetic tilapia types.

\section{MATERIALS AND METHODS}

Fish. Two tilapia types were used, MT and PU (see Muñoz-Córdova \& Garduño-Lugo 2003). Fish were donated by the Centro de Enseñanza, Investigación y Extensión en Ganadería Tropical, Universidad Nacional Autónoma de México (UNAM), and had been transported to the Acuario de Veracruz 3 wk before the start of salinity acclimatization. Fish were acclimatized to salinity in $1.2 \mathrm{~m}^{3}$ ( $1 \mathrm{~m}$ long $\times 1 \mathrm{~m}$ wide $\times 0.85 \mathrm{~m}$ high) flow-through tanks using filtered seawater mixed with decreasing amounts of filtered, dechlorinated tap freshwater. Starting with $100 \%$ freshwater, 5\% increments in salinity were made gradually until seawater salinity $(35 \%)$ was reached within ca. 3 wk. Salinity was measured daily with a refractometer, and 2 to 3 water changes (30 to $40 \%$ of total water volume) were made to maintain adequate physicochemical parameters. The mean water temperature throughout the experiments was $29^{\circ} \mathrm{C}$. All procedures were performed at the Acuario de Veracruz facilities and approved by the ethical review board of the Veterinary Medicine School, UNAM.

Parasite collection. Individual fish were immersed for $10 \mathrm{~min}$ in $5 \mathrm{l}$ of filtered, dechlorinated tap freshwater and gently massaged to physically dislodge as many Neobenedenia sp. as possible (Fajer-Ávila et al. 2008); fish were observed during this treatment to ensure they were not distressed. Dead parasites turned creamy white and were collected by filtering the bath water through a fine cloth (50 $\mu \mathrm{m}$ mesh size). No quantitative study was made on the efficiency of freshwater baths in removing parasites, but several treated fish were inspected under the microscope following the freshwater bath, and no worms were detectedalthough it is possible that during our quick inspection some transparent, living parasites remained unnoticed. Dead worms were either immediately placed in Petri dishes and counted under a dissection microscope, or preserved in $70 \%$ ethanol for later analysis. During microscopic examination, the adult status of parasites (i.e. sexual maturity and ability to produce eggs) was assessed by the presence of the vitellarium and/or signs of egg production. Fixed worms were identified to the generic level by Ian Whittington (South Australian Museum, Adelaide). Voucher specimens of Neobenedenia sp. were deposited in the Colección Nacional de Helmintos, Universidad 
Nacional Autónoma de México, Mexico City (Catalogue number CNHE 7447).

Immunization. Parasites collected and fixed in $70 \%$ ethanol during the original Neobenedenia sp. outbreak in September 2008 were washed in clean 96\% ethanol. Several hundreds of ethanol-moist whole worms of different sizes (range ca. 0.5 to $4 \mathrm{~mm}$ ) were ground in a glass mortar until ca. $1 \mathrm{ml}$ of worm paste was obtained; this paste was mixed with $1 \mathrm{ml}$ of sterile injection water. One $\mathrm{ml}$ of the resulting worm solution was added to a new, $10 \mathrm{ml}$ bottle of Freund's complete adjuvant (FCA; Sigma-Aldrich), mixed well, and kept at $4^{\circ} \mathrm{C}$ until used $1 \mathrm{wk}$ later; we called this preparation crude worm extract. In October 2008, separate stocks of salinity-acclimatized, naïve fish (not exposed to the original Neobenedenia sp. outbreak or unfiltered seawater) were used in the immunization trials. A total of 30 naïve PU and 30 naïve MT were immunized 1 mo before exposure to unfiltered seawater: each fish was inoculated intraperitoneally (i.p.) with $40 \mu$ l of the crude worm extract. Prior to each injection, the crude worm extract was vigorously mixed with a vortex to form an emulsion. Simultaneously, 30 naïve control animals of each genetic type received $40 \mu$ FCA i.p. without worm extract. Immunized fish were identified by clipping their dorsal fins.

Parasite challenge. Unfiltered seawater pumped from the Gulf of Mexico at the port of Veracruz is the source of Neobenedenia sp. infection at the Acuario de Veracruz, as fish from the original outbreak started acquiring parasites after exposure to it. No information is available on the local Neobenedenia spp. hosts off Veracruz, but probable sources of infection include tropical fish known to harbor $N$. melleni in the Caribbean Sea (Kohn et al. 2006), as some of these fish also occur off the port of Veracruz, Mexico. In November 2008, experimentally immunized and control tilapia were housed in $1 \mathrm{~m}^{3}(1 \mathrm{~m}$ long $\times 1 \mathrm{~m}$ wide $\times 1 \mathrm{~m}$ high) floating cages placed in a $56.5 \mathrm{~m}^{3}$ (6 m diam. $\times 2$ $\mathrm{m}$ high) circular tank exposed to unfiltered seawater: 2 cages containing 60 fish each were used (15 immunized PU, 15 control PU, 15 immunized MT, 15 control MT). Fish mortality was recorded daily during the study; mortality of the experimental groups was contrasted to that of the naïve fish stocks from which immunized and control hosts were taken, which were not exposed to unfiltered seawater. As exposure to unfiltered seawater resulted in infection, days post exposure were considered as days post infection (dpi). On each parasite census dpi, 10 fish of each experimental group (5 from each cage) were bathed in freshwater to collect parasites. During sampling, fish were measured (fork length), and spines of their dorsal fin were clipped to identify them and avoid repeated sampling; after this, fish were returned to their cages. The sampling regime and sample sizes are shown in Table 1. By 18 dpi, all PU had died and all surviving MT had been previously sampled for parasites. Thus, parasitological and mortality data obtained 18 and $21 \mathrm{dpi}$, which represent parasite burdens acquired during unknown periods of time, were not used for parasitological or survival analyses. Nonetheless, mean parasite abundances recorded on MT on these days are shown to illustrate the burdens of fish kept in enclosed systems, as well as the rapid increase of parasite populations.

Statistical analysis. Fish sizes were compared by means of $t$-tests using the software Minitab 15. Use of parasitological parameters follows Bush et al. (1997). Parasite mean abundances and their 95\% confidence intervals were calculated and compared in bootstrap $t$ tests, with 2000 replications using the software Quantitative Parasitology 3.0 (Rózsa et al. 2000). Survival plots were calculated by the Kaplan-Meier method and compared with a Wilcoxon test using Minitab 15.

\section{RESULTS}

Exposure of experimental fish to unfiltered seawater resulted in Neobenedenia sp. infection: starting on Day 3 pi, parasites were recovered from exposed tilapia (PU mean abundance 1.25 worms fish ${ }^{-1}, 40 \%$ prevalence; MT 1.56 worms fish ${ }^{-1}, 45 \%$ prevalence). Mean standard lengths of PU $(8.01 \mathrm{~cm})$ and MT $(7.69 \mathrm{~cm})$ were not significantly different $(p=0.132)$. Immunization had no effect in reducing the number of worms fish ${ }^{-1}$ following exposure to infection: on Days 3 through 15 pi, Neobenedenia sp. abundance did not differ significantly between immunized and control fish for either PU or MT (data not shown; all

Table 1. Sampling regime and sample sizes of control and immunized PargoUNAM (PU) and Mozambique tilapia Oreochromis mossambicus (MT) inspected for Neobendenia sp. infection. pi: day post-infection, n/a: not available (all fish from that group had died)

\begin{tabular}{|c|c|c|c|c|c|c|c|c|}
\hline \multirow[t]{2}{*}{ Fish group } & \multicolumn{8}{|c|}{ Sample size at Day pi } \\
\hline & 3 & 5 & 7 & 9 & 12 & 15 & 18 & 21 \\
\hline Control PU & 10 & 10 & 10 & 10 & 8 & 3 & $\mathrm{n} / \mathrm{a}$ & $\mathrm{n} / \mathrm{a}$ \\
\hline Immunized PU & 10 & 10 & 10 & 10 & 7 & 1 & $\mathrm{n} / \mathrm{a}$ & $\mathrm{n} / \mathrm{a}$ \\
\hline Control MT & 10 & 10 & 10 & 10 & 10 & 10 & $10^{\mathrm{a}}$ & $10^{\mathrm{a}}$ \\
\hline Immunized MT & 10 & 10 & 10 & 10 & 10 & 10 & $10^{\mathrm{a}}$ & $10^{\mathrm{a}}$ \\
\hline
\end{tabular}


$\mathrm{p}$ values $>0.05)$. Survival plots of immunized and control fish (both PU and MT) did not differ significantly in the same period (data not shown). Thus, data from immunized and control fish obtained on Days 3 through 15 pi were pooled and analyzed further as 2 groups, PU and MT (Figs. 1 \& 2).

Levels of Neobenedenia sp. on PU and MT increased gradually until Day 9 pi, with both prevalence and abundance of infection rising steadily (Fig. 1). No significant differences in abundance were detected in this period between PU and MT (data not shown, all p-values $>0.05$ ). On Day 12 pi, a sudden rise in parasite abundance was observed, and prevalence of infection reached $100 \%$ in both tilapia groups, with parasite burdens not differing significantly between them $(\mathrm{p}=$ 0.442): PU had a mean abundance of 51.3 worms fish $^{-1}$ (range 13 to 99 worms fish $^{-1}$ ), while MT presented a mean of 62.4 worms fish ${ }^{-1}$ (range 7 to 178 worms

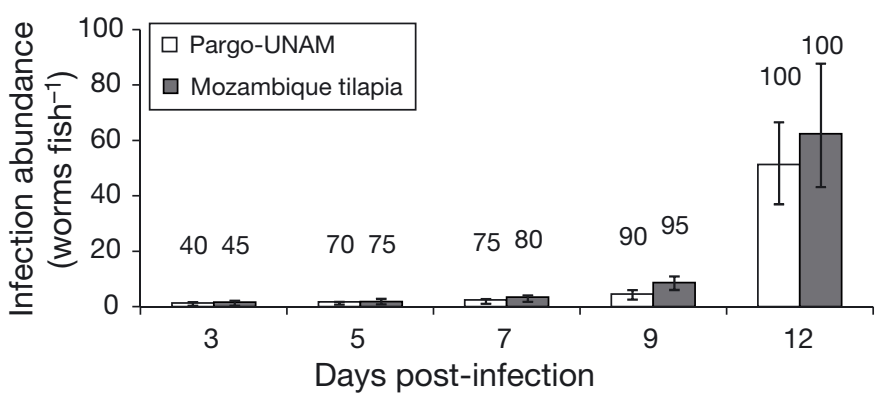

Fig. 1. Mean abundance of Neobenedenia sp. infecting Mozambique tilapia Oreochromis mossambicus (MT) and Pargo-UNAM (PU), a synthetic hybrid tilapia, following exposure to unfiltered seawater off the Gulf of Mexico. Bars show mean values and $95 \%$ confidence intervals. Values above abundance bars indicate prevalence of infection

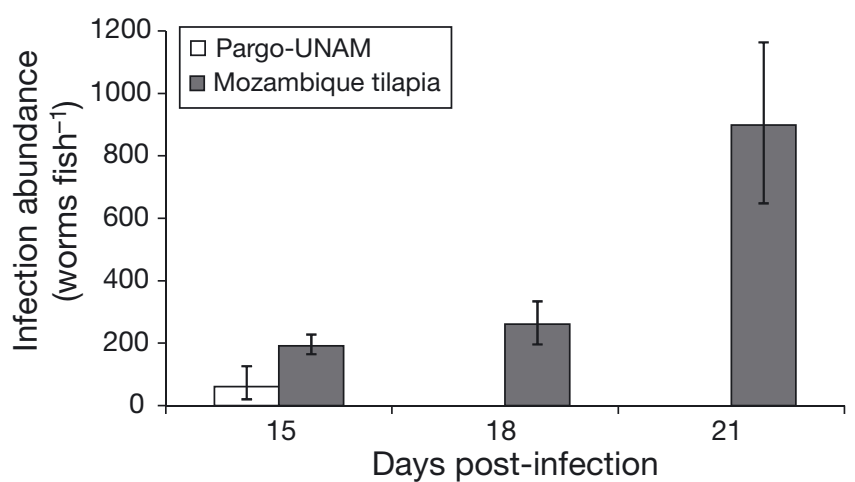

Fig. 2. Mean abundance of Neobenedenia sp. infecting Mozambique tilapia Oreochromis mossambicus and PargoUNAM, following exposure to unfiltered seawater off the Gulf of Mexico. Bars show mean values and $95 \%$ confidence intervals. Note that data shown for Days 18 and 21 postinfection (pi) are only illustrative, as samples were taken on Days 18 and 21 pi but were not strictly representative of that length of exposure, as fish had been previously sampled fish $^{-1}$ ). However, despite similar parasite abundances from the start of exposure through to $12 \mathrm{dpi}$, infected PU and MT differed considerably in survival rates. By Day 12 pi, PU had experienced $78 \%$, and MT $30 \%$ mortality (Fig. 3). Although no pathological examinations were made on dead/dying experimental fish, mortality was considered to result from Neobenedenia sp. infection (and/or secondary opportunistic infections), as no deaths were recorded in the naïve, salinity-acclimatized tilapia stocks not exposed to unfiltered seawater. In all parasite samples, a considerable size range (ca. 1 to $4 \mathrm{~mm}$ ) was observed among adult worms. On Day 15 pi (Fig. 2), parasite abundance was significantly higher $(\mathrm{p}=0.014)$ in MT (mean 191.2, range 65 to 366 worms fish ${ }^{-1}$ ) than in PU (mean 61.3, range 18 to 151 worms fish ${ }^{-1}$ ); however, only 4 surviving PU were compared to 20 surviving MT (Table 1). Following Neobenedenia sp. infection, the mean survival time calculated for MT (13.9 d) was significantly higher than that for PU (8.3 di p = 0.0001) (Fig. 3).

Abundance data obtained for MT 18 and 21 dpi represent unknown exposure periods, as all fish had been previously sampled. Nonetheless, data show that $22 \%$ of MT survived longer than PU (potentially up to 21 dpi) despite their high parasite burdens (mean abundance 21 dpi was 898.4, range 182 to 1923 worms fish $^{-1}$; Fig. 2). These data also show that parasite abundance (and therefore the rate of parasite acquisition) increased noticeably twice during the study period: the first time between Days 9 and 12 pi, the second between Days 18 and 21 pi.

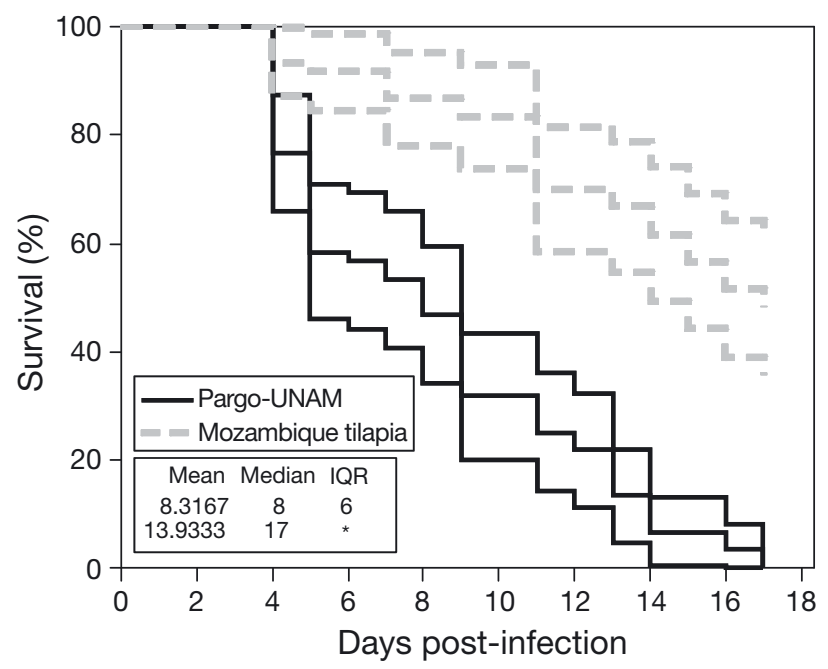

Fig. 3. Survival plot for Mozambique tilapia Oreochromis mossambicus (solid black line) and Pargo-UNAM (gray dashed line) infected with Neobenedenia sp. Plots were calculated using the Kaplan-Meier method and include 95\% confidence intervals. IQR: interquartile range; *: outlier (not shown in plot). All units are days pi 


\section{DISCUSSION}

Immunization of tilapia with whole worm crude extracts of Neobenedenia sp. did not confer any protection against infection, as assessed by comparing parasite abundances of immunized and control fish. Likewise, although Japanese flounder Paralichthys olivaceus Temminck \& Schlegel developed partial resistance to secondary infection with $N$. girellae, immunization with crude parasite extracts did not confer any protection (Bondad-Reantaso et al. 1995). Interestingly, the first reports of fish developing immunity against monogenean infections came from the New York Aquarium, where it was noticed that abundances of $N$. melleni were higher in naïve fish than in previously infected fish (Jahn \& Kuhn 1932, Nigrelli \& Breder 1934). Thus, development of vaccines against these ectoparasites might be feasible, considering that several fish species have been reported to develop resistance to secondary infections with both N. melleni (see Nigrelli \& Breder 1934, Nigrelli 1947, Buchmann \& Bresciani 2006) and $N$. girellae (see Ohno et al. 2008). Immunization of Japanese flounder $P$. olivaceus with a ciliary surface glycoprotein of $N$. girellae elicits the production of antibodies which agglutinate/immobilize oncomiracidia, and which can be detected in both fish serum and mucus - but induces no protection against infection (Hatanaka et al. 2005). Availability of the cloned cathepsin L-like cysteine protease from $N$. melleni (see Rao \& Yang 2007) provides a further potential target molecule for both pharmacological and vaccination-mediated controls.

In the present study, immunization failed to confer resistance to Neobenedenia sp., but this vaccination trial enabled us to analyze the dynamics of infection and of parasite-induced host mortality. Although no pathological studies were conducted to ascertain that fish mortality was due to infection with Neobenedenia sp. (and/or ensuing secondary infections), we propose this was the case, for 2 reasons: (1) no mortality was recorded in the fish stocks from which our experimental fish came but which were not exposed to unfiltered seawater and thus were not infected; (2) detailed studies of the effects of $N$. girellae on amberjack Seriola dumerili Risso have shown that parasites severely damage hosts shortly after infection (Hirayama et al. 2009). Our observation that adult parasites varied considerably in size might be related to their pathogenicity, as this variation could be a consequence of worms maturing early and growing rapidly (I. Whittington pers. comm.). Data on the dynamics of Neobenedenia sp. infection demonstrated that parasite acquisition was gradual during the first $9 \mathrm{dpi}$, and that parasite abundance increased noticeably between 9 and 12 dpi, possibly reflecting the recruitment of a second parasite generation originating from eggs entangled on the net of the floating cages - a further sudden increase of parasite abundance observed between 18 and $21 \mathrm{dpi}$ might correspond to a third parasite generation. Up to 12 dpi, mean parasite abundances did not differ significantly between tilapia groups, i.e. MT and PU were equally resistant to infection with Neobenedenia sp. As proposed recently (Read et al. 2008), susceptibility encompasses 2 different but complementary host traits that together determine how harmful an infection is: resistance and tolerance. Resistance refers to the ability to limit parasite burdens, while tolerance is the ability to limit the health or fitness consequences of a given parasite burden. Therefore, although in our case PU and MT exhibited similar resistance to Neobenedenia sp., they differed markedly in tolerance. The different host tolerance is illustrated by the observation that a mean intensity of ca. 50 worms fish ${ }^{-1}$ killed all PU within a fortnight, while $22 \%$ of MT survived longer (possibly up to $3 \mathrm{wk}$ pi), harboring mean parasite abundances of ca. 900 worms fish ${ }^{-1}$. As pointed out by Read et al. (2008), resistance and tolerance are not absolute manifestations, as these depend on the particular pathogens to which hosts are exposed. Indeed, the same hosts studied here differed in their resistance to the monogenean Gyrodactylus cichlidarum Paperna, 1968 (PU harboring significantly higher parasite burdens than MT), but were similarly tolerant to infection (as neither tilapia type exhibited mortality or measurable effects of infection over a 1 yr period) (M. RubioGodoy unpubl. data). Differences in resistance to infection shown by diverse salmonid species have been linked to variation in the ability of immune factors to destroy monogenean parasites; examples include differential resistance to Gyrodactylus derjavini Mikhailov, 1975 (see Buchmann \& Uldal 1997) and to Discocotyle sagittata (Leuckart, 1842) Diesing, 1850 (see Rubio-Godoy et al. 2004). Similarly, yellowtail Seriola quinqueradiata Temminck \& Schlegel, amberjack $S$. dumerili, and Japanese flounder $P$. olivaceus differ in their susceptibility to infection by $N$. girellae (see Ohno et al. 2008)

The present study expands the western range of Neobenedenia sp. in the Gulf of Mexico/Caribbean Sea region: we recorded the parasite at the port of Veracruz $\left(19^{\circ} 11^{\prime} \mathrm{N}, 96^{\circ} 07^{\prime} \mathrm{W}\right)$, and it had been previously reported infecting tilapias off Martinique $\left(14^{\circ} 40^{\prime} \mathrm{N}, 61^{\circ} 00^{\prime} \mathrm{W}\right)$, the Bahamas $\left(25^{\circ} 4^{\prime} \mathrm{N}, 77^{\circ} 20^{\prime} \mathrm{W}\right)$, and Jamaica $\left(17^{\circ} 59^{\prime} \mathrm{N}, 76^{\circ} 48^{\prime} \mathrm{W}\right)$. Tropical marine fish are likely to be the source of parasites in the Gulf of Mexico/Caribbean, as Neobenedenia spp. have been recovered from several wild fish in this region (Kohn et al. 2006). In particular, the following fish species are known N. melleni hosts and occur off Veracruz: doctor- 
fish Acanthurus chirurgus, rock hind Epinephelus adscensionis, yellowtail snapper Ocyurus chrysurus, smooth trunkfish Rhinesomus (= Lactophrys) triqueter; spot-fin porcupinefish Diodon hystrix, spotfin butterflyfish Chaetodon ocellatus, and French angelfish Pomacanthus paru. Our results suggest that infection with Neobenedenia sp. might significantly limit tilapia mariculture on the coastline of the Mexican state of Veracruz.

Acknowledgements. We thank Germán Muñoz-Córdova and Mario Garduño-Lugo (Centro de Enseñanza, Investigación y Extensión en Ganadería Tropical; CEIEGT, UNAM) for kindly donating experimental fish; Ian Whittington (South Australian Museum) for taxonomic identification of the parasites; and 2 anonymous reviewers for suggestions that improved the manuscript. This work was supported by grants FOMIX 32679 and CB 58050 awarded to M.R.-G.

\section{LITERATURE CITED}

Bondad-Reantaso MG, Ogawa K, Yoshinaga T, Wakabayashi $\mathrm{H}$ (1995) Acquired protection against Neobenedenia girellae in Japanese flounder. Fish Pathol 30:233-238

Breves JP, Hasegawa S, Yoshioka M, Fox BK and others (2010) Acute salinity challenges in Mozambique and Nile tilapia: differential responses of plasma prolactin, growth hormone and branchial expression of ion transporters. Gen Comp Endocrinol 167:135-142

Buchmann K, Bresciani J (2006) Monogenea (phylum Platyhelminthes). In: Woo PTK (ed) Fish diseases and disorders, Vol 1. Protozoan and metazoan infections. CAB International, Wallingford, p 297-344

Buchmann K, Uldal A (1997) Gyrodactylus derjavini infections in four salmonids: comparative host susceptibility and site selection of parasites. Dis Aquat Org 28: 201-209

Bunkley-Williams L, Williams EHJ (1994) Parasites of Puerto Rican freshwater sport fishes. Puerto Rico Department of Natural and Environmental Resources, and Department of Marine Sciences, University of Puerto Rico, San Juan and Mayagüez

Bush AO, Lafferty KD, Lotz JM, Shostak AW (1997) Parasitology meets ecology on its own terms: Margolis et al. revisited. J Parasitol 83:575-583

Cowell LE, Watanabe WO, Head WD, Grover JJ, Sheaker JM (1993) Use of tropical cleaner fish to control the ectoparasite Neobenedenia melleni (Monogenea, Capsalidae) on seawater-cultured Florida red tilapia. Aquaculture 113: $189-200$

> Deveney MR, Chisholm LA, Whittington ID (2001) First published record of the pathogenic monogenean parasite Neobenedenia melleni (Capsalidae) from Australia. Dis Aquat Org 46:79-82

Ellis EP, Watanabe WO (1993) The effects of hyposalinity on eggs, juveniles and adults of the marine monogenean, Neobenedenia melleni. Treatment of ecto-parasitosis in seawater-cultured tilapia. Aquaculture 117:15-27

Fajer-Ávila EJ, Martínez-Rodríguez I, de la Parra MIA, Álvarez-Lajonchere L, Betancourt-Lozano M (2008) Effectiveness of freshwater treatment against Lepeophtheirus simplex (Copepoda: Caligidae) and Neobenedenia sp. (Monogenea: Capsalidae), skin parasites of bullseye puffer fish, Sphoeroides annulatus reared in tanks. Aquaculture 284:277-280

FAO (2008) FishStat Plus. Food and Agriculture Organization of the United Nations, Rome

Gallet de St. Aurin D, Raymond JC, Vianas V (1990) Marine finfish pathology: specific problems and research in the French West Indies. Actes Colloq 9:143-160

Hatanaka A, Umeda N, Yamashita S, Hirazawa N (2005) A small ciliary surface glycoprotein of the monogenean parasite Neobenedenia girellae acts as an agglutination/ immobilization antigen and induces an immune response in the Japanese flounder Paralichthys olivaceus. Parasitology 131:591-600

> Hirayama T, Kawano F, Hirazawa N (2009) Effect of Neobenedenia girellae (Monogenea) infection on host amberjack Seriola dumerili (Carangidae). Aquaculture 288:159-165

> Hirazawa N, Mitsuboshi T, Hirata T, Shirasu K (2004) Susceptibility of spotted halibut Verasper variegatus (Pleuronectidae) to infection by the monogenean Neobenedenia girellae (Capsalidae) and oral therapy trials using praziquantel. Aquaculture 238:83-95

> Jahn TL, Kuhn LR (1932) The life history of Epibdella melleni MacCallum 1927, a monogenetic trematode parasitic on marine fishes. Biol Bull 62:89-111

Kaneko JJ, II, Yamada R, Brock JA, Nakamura RM (1988) Infection of tilapia, Oreochromis mossambicus (Trewavas), by a marine monogenean, Neobenedenia melleni (MacCallum, 1927) Yamaguti, 1963 in Kaneohe Bay, Hawaii, USA, and its treatment. J Fish Dis 11:295-300

Kohn A, Cohen SC, Salgado-Maldonado G (2006) Checklist of Monogenea parasites of freshwater and marine fishes, amphibians and reptiles from Mexico, Central America and Caribbean. Zootaxa 1289:1-114

Lazard J (2009) Tilapia fish farming. Cah Agric 18:174-182

MacCallum GA (1927) A new ectoparasitic trematode, Epibdella melleni, sp. nov. Zoopathol 1:291-300

McCammon A, Sikkel PC, Nemeth D (2010) Effects of three Caribbean cleaner shrimps on ectoparasitic monogeneans in a semi-natural environment. Coral Reefs 29: 419-426

Mueller KW, Watanabe WO, Head WD (1992) Effect of salinity on hatching in Neobenedenia melleni, a monogenean ectoparasite of seawater-cultured tilapia. J World Aquacult Soc 23:199-204

> Mueller KW, Watanabe WO, Head WD (1994) Occurrence and control of Neobenedenia melleni (Monogenea, Capsalidae) in cultured tropical marine fish, including three new host records. Prog Fish-Cult 56:140-142

Muñoz-Córdova G, Garduño-Lugo M (2003) Mejoramiento genético en tilapia: sistemas de cruzamiento y mecanismos genéticos en la determinación de color. Sistema de Investigación del Golfo de México del Consejo Nacional de Ciencia y Tecnología, Veracruz

Nigrelli RF (1947) Susceptibility and immunity of marine fishes to Benedenia (=Epibdella) melleni (McCallum), a monogenean trematode. III. Natural hosts in the West Indies. J Parasitol 33:25

Nigrelli RF, Breder CM (1934) The susceptibility and immunity of certain marine fishes to Epibdella melleni, a monogenetic trematode. J Parasitol 20:259-269

> Ohashi H, Umeda N, Hirazawa N, Ozaki Y, Miura C, Miura T (2007) Antiparasitic effect of calcium and magnesium ionfree buffer treatments against a common monogenean Neobenedenia girellae. Parasitology 134:229-236

> Ohno Y, Kawano F, Hirazawa N (2008) Susceptibility by amberjack (Seriola dumerili), yellowtail (S. quinqueradi- 
ata) and Japanese flounder (Paralichthys olivaceus) to Neobenedenia girellae (Monogenea) infection and their acquired protection. Aquaculture 274:30-35

Ohno Y, Kawano F, Hirazawa N (2009) The effect of oral antibiotic treatment and freshwater bath treatment on susceptibility to Neobenedenia girellae (Monogenea) infection of amberjack (Seriola dumerili) and yellowtail ( $S$. quinqueradiata) hosts. Aquaculture 292:248-251

Rao YZ, Yang TB (2007) cDNA cloning, mRNA expression and recombinant expression of a cathepsin L-like cysteine protease from Neobenedenia melleni (Monogenea: Capsalidae). Aquaculture 269:41-53

Read AF, Graham AL, Råberg L (2008) Animal defenses against infectious agents: Is damage control more important than pathogen control? PLoS Biol 6:e1000004

Robinson RD, Khalil LF, Hall RN, Steele RD (1992) Infection of red hybrid tilapia with a monogenean in coastal waters off southern Jamaica. Proc Gulf Caribb Fish Inst 42:441-447

Robinson RD, O'Connor NPG, Steele RD (2008) Interactions between cage-cultured hybrid tilapia and a marine monogenean, Neobenedenia melleni, in Jamaica. N Am J Aquac 70:68-73

Editorial responsibility: Robert Poulin,

Dunedin, New Zealand
Rózsa L, Reiczigel J, Majoros G (2000) Quantifying parasites in samples of hosts. J Parasitol 86:228-232

Rubio-Godoy M, Porter R, Tinsley RC (2004) Evidence of complement-mediated killing of Discocotyle sagittata (Platyhelminthes, Monogenea) oncomiracidia. Fish Shellfish Immunol 17:95-103

Sikkel PC, Nemeth D, McCammon A, Williams EH (2009) Habitat and species differences in prevalence and intensity of Neobenedenia melleni (Monogenea: Capsalidae) on sympatric Caribbean surgeonfishes (Acanthuridae). J Parasitol 95:63-68

Thoney DA, Hargis WHJ (1991) Monogenea (Platyhelminthes) as hazards for fish in confinement. Annu Rev Fish Dis 1:133-153

Whittington ID (2004) The Capsalidae (Monogenea: Monopisthocotylea): a review of diversity, classification and phylogeny with a note about species complexes. Folia Parasitol (Praha) 51:109-122

Whittington ID, Horton MA (1996) A revision of Neobenedenia yamaguti, 1963 (Monogenea: Capsalidae) including a redescription of $N$. melleni (MacCallum, 1927) Yamaguti, 1963. J Nat Hist 30:1113-1156

Submitted: June 8, 2010; Accepted: September 17, 2010

Proofs received from author(s): November 25, 2010 